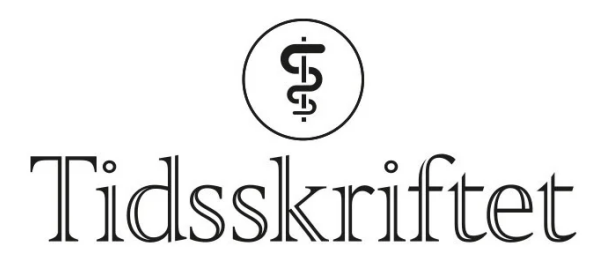

DEN NORSKE LEGEFORENING

\title{
Paradokser og ulikheter i norsk helsevesen
}

KRONIKK

\section{REIDUN FØRDE}

reidun.forde@medisin.uio.no

Reidun Førde er dr.med. og professor ved Senter for medisinsk etikk, Universitetet i Oslo og er nestleder i klinisk etikk-komité ved Oslo universitetssykehus.

Forfatteren har fylt ut ICMJE-skjemaet og oppgir ingen interessekonflikter.

\section{INGVILD STRAND HOVLAND}

Ingvild Strand Hovland er spesialist i psykiatri, overlege og tilsynspsykiater ved Akuttmedisinsk avdeling, Oslo universitetssykehus.

Forfatteren har fylt ut ICMJE-skjemaet og oppgir ingen interessekonflikter.

\section{ASLAK SYSE}

Aslak Syse er dr.juris, lege og professor emeritus ved Institutt for offentlig rett, Universitetet i Oslo og medlem av Forskningsetisk komité, Norges miljø- og biovitenskapelige universitet.

Forfatteren har fylt ut ICMJE-skjemaet og oppgir ingen interessekonflikter.

\section{OONA DUNLOP}

Oona Dunlop er ph.d. og overlege ved Nasjonal behandlingstjeneste for CBRNE-medisin (CBRNEsenteret) og Akuttmedisinsk avdeling, Oslo universitetssykehus. Hun er leder for klinisk etikkomité ved Oslo universitetssykehus.

Forfatteren har fylt ut ICMJE-skjemaet og oppgir ingen interessekonflikter.

\section{Ulike pasientgrupper, alle med livstruende lidelser og selvskadende adferd, blir behandlet ulikt, selv om de har lik alder og nokså lik prognose.}

Denne artikkelen springer ut fra drøftinger i klinisk etikk-komitéer (KEK) rundt pasienter som blir intensivbehandlet med omfattende ressursbruk, inkludert bruk av tvang. Etter et slikt drøftingsmøte har involverte klinikere uttrykt undring over hvordan ulike pasientgrupper blir behandlet ulikt. I det følgende vil vi bruke konstruerte sykehistorier sammensatt av mange ulike pasienter for å illustrere noen paradokser.

\section{Pasient 1 - anoreksi}


En kvinne i 2o-årene legges inn på intensivavdeling med truende multiorgansvikt på grunn av grov avmagring. Hun har hatt spiseforstyrrelser i 12 år. Det besluttes at det er grunnlag for tvangsinnleggelse etter psykisk helsevernloven $\S 3^{-2}$ og tvangsernæring med hjemmel i $\S 4-4$. I tillegg til å ha fastvakter hele døgnet både fra psykiatrisk og intensiv avdeling må hun sederes tungt og legges i belter i lange perioder.

Etter mange uker bedres allmenntilstanden. Hun ønsker nå psykiatrisk behandling og hun $\emptyset n s k e r$ å leve. Hun beskriver tvangen som terror, at den har økt hennes angst og reaktivert tidligere traumer. Hun vet at hun kan dø uten tvang, men det er hun forberedt på. Hun blir overført til psykiatrisk avdeling.

\section{Pasient 2 - suicidalitet}

Samtidig innlegges en kvinne i 3o-årene etter et alvorlig selvmordsforsøk. Hun står midt i en skilsmisse, og dette er hennes tredje alvorlige forsøk på kort tid. Hun gjennomgår intensivbehandling i tre døgn. Hun er ikke alvorlig deprimert og sier hun nå vil leve for barna. Hun bedømmes som samtykkekompetent. Pårørende mener at det er overhengende fare for pasientens liv og ønsker tvangsinnleggelse i psykiatrisk institusjon for å beskytte henne mot seg selv. Dette ønsker ikke pasienten, og hun blir overført til distriktspsykiatrisk senter, som hun forlater dagen etter.

\section{Pasient 3 - rus}

En mann i 2o-årene som behandles samtidig på en intensivavdeling er godt kjent etter flere innleggelser med svært høy promille. Pasienten er utagerende og må tvangsbehandles for å motta livreddende behandling.

Han klarer ikke å møte til planlagt poliklinisk oppfølging. Frivillig døgnbehandling har vært forsøkt. Mor sier at sønnen ønsker hjelp, men det er for lang ventetid på tilbudene. Det blir vurdert at det ikke er riktig å holde ham tilbake med tvang.

\section{Insidens og mortalitet}

Det hefter usikkerhet ved tall for insidens og mortalitet for disse pasientgruppene. Anorexia nervosa har med en streng definisjon av diagnosen en insidens på ca. 20/10o ooo

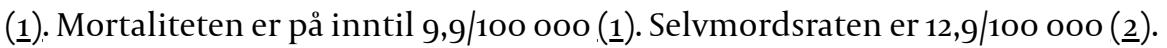

For rusavhengighet var dødsraten 8,9/100 ooo (3). For pasienter innlagt med selvpåført forgiftning etter rus eller suicidforsøk har vi tall fra Oslo som viser en insidens på 70o/10o ooo per år (4), median alder ved innleggelse er 31 år. 20-årsmortaliteten er på 37 \% (5).

For anoreksipasienter viser tall at etter 10 og 20 år er hhv. ca. 30 \% og ca. 60 \% friske (ㅁ). I alle pasientgruppene er mangel på forskning et problem.

\section{Lovverket gir rammene}

Norsk helsetjeneste er regulert av et omfattende lovverk (7-9.). Som hovedregel skal pasienten samtykke til all behandling. Behandlingen skal gis etter en individuell vurdering. For hver enkelt pasient må man vurdere hva som er til pasientens beste. Dette gjelder også med hensyn til ressursbruk og tvangsbruk. For at helsehjelp skal prioriteres, må det være et rimelig forhold mellom nytten og ressursbruken. Rettferdighet og likebehandling er bærende prinsipper. Forskjellsbehandling bør derfor begrunnes. 
Det siste tiåret har det vært stort fokus på bruken av tvang i helsetjenesten, særlig innen psykiske helsetjenester. De negative følgene av å bli utsatt for tvang har vært framhevet (10,11). Bruken av tvang i somatiske helsetjenester ble lovregulert i 2009 i pasient- og brukerrettighetsloven kapittel 4A.

At det er to ulike lovverk for tvangsbruk i psykiske og somatiske helsetjenester, er krevende, især hos pasienter med både somatiske og psykiske sykdommer. Dette forekommer hyppig og er opphav til kompliserte etiske og juridiske dilemmaer (12).

"Selv om de lovgitte kriteriene for bruk av tvang er oppfylt, må det vurderes om tvang eller ikke er til pasientens beste»

Tvangslovsutvalget ble nedsatt for å samle all tvangsbruk i et felles lovverk (13). Samtykkekompetanse, som de siste tiårene har fătt en sentral plass, er ikke alltid enkelt å vurdere i klinisk praksis. I tolkningen og anvendelsen av lovene oppstår det gråsoner som fordrer evner til etisk refleksjon. Selv om de lovgitte kriteriene for bruk av tvang er oppfylt, må det vurderes om tvang eller ikke er til pasientens beste. Det må også vektes mot hensyn til andre berørte parter og forsvarlig ressursbruk. I vurderingen må graden av motstand vektlegges og om pasienten i nær framtid vil kunne gjenvinne samtykkekompetansen.

Bruk av tvang har også en ressursside. Vi vet at i noen tilfeller får sykehjemspasienter medisiner for å roes ned på grunn av mangel på personalressurser (14).). Omfattende bruk av tvang er ressurskrevende og emosjonelt krevende for personalet.

\section{Drøftinger}

I denne artikkelen stiller vi spørsmål rundt forskjellsbehandlingen av disse pasientene. Alle har psykiatriske sykdommer i bunnen og er livstruende somatisk syke. De blir reddet gjennom intensivbehandling, men det videre forløpet er forskjellig. Intensivressursene som ble brukt, er mindre nyttige dersom oppfølgingen ikke gir varig overlevelse.

\section{SAMTYKKEKOMPETANSEN}

Ulik praksis rundt disse tre pasientgruppene har sannsynligvis flere forklaringer. En viktig forskjell er ulik samtykkekompetanse, som igjen har betydning for lovlig bruk av tvang.

Anoreksipasienten fyller kravene til samtykkekompetanse i en rekke valgsituasjoner når den somatiske tilstanden er normalisert (15). Om hun er samtykkekompetent når det gjelder sin grunnlidelse, er mer tvilsomt. Det er derfor hjemmel i loven for å kunne tvangsbehandle alvorlig anoreksi uavhengig av samtykkekompetanse.

\section{«For oss er det ulogisk at man ikke kan bruke noe tvang hos en pasient $i$}

livskrise/akutt suicidalfare, utover øyeblikkelig hjelp»

Den suicidale pasienten er samtykkekompetent. Hun forstår at hun kan døav selvmordsforsøkene. I praksis ser vi at suicidale pasienter på grunn av sin samtykkekompetanse er ubeskyttet mot seg selv, og hjelpeapparatet er juridisk «lammet» fra å hjelpe. Det er paradoksalt at når pasienten innlegges med behov for øyeblikkelig somatisk hjelp, kan behandling gjennomføres med hjemmel i helsepersonelloven § 7 uavhengig av motstand og samtykke. Men det er neppe hjemmel for videre tvangsbehandling av den psykiske lidelsen når pasienten ikke har en «alvorlig sinnslidelse» i psykisk helsevernlovens forstand.

Ruspasienten kan sies å ha redusert samtykkekompetanse basert på samme logikk som anoreksipasienten. Han er samtykkekompetent på de fleste områder, men ikke når det gjelder valg rundt rus. Ofte vil man lande på at ruspasienter skal oppfattes som 
samtykkekompetente. For tvangsinnleggelser etter helse- og omsorgstjenesteloven kapittel 10 er det egne tvangsregler, og innleggelse bestemmes av fylkesnemnda for barnevern og sosiale saker $(\underline{16})$.

\section{NYTTE VERSUS RESSURSBRUK}

Nytten av behandling må antas å være størst hos pasienten med livskrisebetinget suicidforsøk dersom hun fikk psykologisk hjelp. Men her kan ikke etterfølgende tvang anvendes i fravær av «alvorlig sinnslidelse». Ut fra en nytte-ressursbruk-vurdering og alvorligheten av tilstanden bør denne pasienten prioriteres og få tilbud om tett oppfølging, eventuelt også kortvarig tvang (gitt lovhjemmel for dette).

Hos pasienter med anoreksi er dødeligheten oftest mindre. Mange kan helbredes, men behandlingen er langvarig og ressurskrevende, ofte med nødvendig tvang og kontroll. Helsevesenets vilje til å bruke ressurser og tvang er langt større for denne pasientgruppen, og lovverket åpner opp for tvang.

\section{«Kanskje kunne noen reddes ved mer bruk av tvungen observasjon?»}

De rusavhengige pasientene har en kronisk alvorlig tilstand, med psykiske, sosiale og somatiske følger. Ruspasienten kan få umiddelbar avrusning, men skrives ofte raskt ut. Det er lang ventetid (måneder) på langtidsbehandling. Behandlingseffekten av intensiv ressursbruk blir derfor liten, og i alle fall forbigående. Dette er uheldig, da en slik situasjon er en mulighet til å initiere endring og motivasjon til videre behandling. Om vedkommende «utsetter sin fysiske eller psykiske helse for fare ved omfattende og vedvarende misbruk, og dersom hjelpetiltak ikke er tilstrekkelig», kan vedkommende innlegges i egnet institusjon i inntil tre måneder for motivasjon (helse- og omsorgstjenesteloven $\S 10-2$ ). For unge rusmisbrukere er det spesielt viktig å intervenere $\mathrm{i}$ en tidlig fase før de får et stort psykososialt og somatisk funksjonsfall. Kanskje kunne et sømløst tilbud fra intensiv via avrusning og over i langtids døgnopphold gi bedre prognose og også være god samfunnsøkonomi?

\section{Er loven logisk?}

I psykisk helsevernloven er alvorlig anoreksi, men ikke rusavhengighet nevnt spesifikt som grunnlag for mulig tvangsbehandling. Suicidalitet kommer inn under alvorlig sinnslidelse bare når pasienten er alvorlig deprimert eller psykotisk. I lovens forarbeider var det ment at ved suicidalitet kunne man gjøre bruk av tvungen observasjon. Det gjøres til en viss grad i dag, men rettsgrunnlaget oppleves som usikkert. Pasienten skrives derfor ofte ut raskt. Observasjonsoppholdet kan i utgangspunktet ikke vare lenger enn ti dager (psykisk helsevernloven §3-2).

For oss er det ulogisk at man ikke kan bruke noe tvang hos en pasient i livskrise/akutt suicidalfare, utover øyeblikkelig hjelp. Ved å bruke kortvarig tvang (dager), kunne man kanskje hjelpe. Kanskje kunne noen reddes ved mer bruk av tvungen observasjon. Selvmordsfaren er aller størst den første uken etter utskrivning (17.). Helsepersonell tolker også loven «feil» når de forsvarer tvangsinnleggelse av selvmordskandidater uten alvorlig psykisk lidelse $(\underline{18}, 19)$.

Tvungen rusbehandling er svært vanskelig å kunne gjennomføre raskt i dag. Det gjeldende lovverket i helse- og omsorgstjenesteloven gjenspeiler den gamle tanken om at ruslidelser er et sosialt/kommunalt problem, selv om behandlingen skjer i spesialisthelsetjenesten. Forbedringer på feltet kan ikke komme uten tilførsel av ressurser, inkludert kompetanse. 


\section{LITTERATUR}

1. Reas DL, Kjelsås E, Heggestad T et al. Characteristics of anorexia nervosa-related deaths in Norway (1992-2000): data from the National Patient Register and the Causes of Death Register. Int J Eat Disord 2005; 37: 181-7. [PubMed][CrossRef]

2. Folkehelseinstituttet. Selvmord i Norge. https://www.fhi.no/nettpub/hin/psykisk-helse/selvmord-inorge/ Lest 19.02.20

3. Folkehelseinstituttet. Narkotikautløste dødsfall i Norge i 2018.

https://www.fhi.no/nettpub/narkotikainorge/konsekvenser-av-narkotikabruk/narkotikautlostedodsfall-i-norge-i-2018/ Lest 19.02.20

4. Heyerdahl F, Bjornaas MAS, Dahl R et al. Repetition of acute poisoning in Oslo: 1-year prospective study. Br J Psychiatry 2009; 194: 73-9. [PubMed][CrossRef]

5. Bjornaas MA, Jacobsen D, Haldorsen T et al. Mortality and causes of death after hospital-treated selfpoisoning in Oslo: a 20-year follow-up. Clin Toxicol (Phila) 2009; 47: 116-23. [PubMed][CrossRef]

6. Eddy KT, Tabri N, Thomas JJ et al. Recovery from anorexia nervosa and bulimia nervosa at 22-year follow-up. J Clin Psychiatry 2017; 78: 184-9. [PubMed][CrossRef]

7. LOV-1999-07-02-64. Lov om helspersonell. https://lovdata.no/dokument/NL/lov/1999-07-02-64 Lest 19.2.2020.

8. LOV-1999-07-02-63. Pasient- og brukerrettighetsloven. https://lovdata.no/dokument/NL/lov/1999o7-02-63?q=pasient\%200g\%2obrukerrettighetsloven Lest 19.2.2020.

9. Helsedirektoratet. Psykisk helsevernlov. https://www.helsedirektoratet.no/tema/psykiskhelsevernloven Lest 19.2.2020.

10. Hammervold UE, Norvoll R, Aas RW et al. Post-incident review after restraint in mental health care -a potential for knowledge development, recovery promotion and restraint prevention. A scoping review. BMC Health Serv Res 2019; 19: 235. [PubMed][CrossRef]

11. Norvoll R, Pedersen R. Exploring the views of people with mental health problems' on the concept of coercion: Towards a broader socio-ethical perspective. Soc Sci Med 2016; 156: 204-11. [PubMed] [CrossRef]

12. Syse I, Førde R, Pedersen R. Clinical ethics committees - also for mental health care? The Norwegian experience. Clin Ethics 2016; 11: 81-6. [CrossRef]

13. Norges offentlige utredninger. Tvangsbegrensningsloven - Forslag til felles regler om tvang og inngrep uten samtykke i helse- og omsorgstjenesten. NOU 2019:14. https://www.regjeringen.no/no/dokumenter/nou-2019-14/id2654803/ Lest 19.2.2020

14. Pedersen R, Hem MH, Gjerberg E et al. Bruk av tvang i sykehjem etter ny lovgivning. Tidsskr Nor Legeforen 2013; 133: 1935-9. [PubMed][CrossRef]

15. Etchells E. Aid To Capacity Evaluation (ACE) - Hjelpemiddel til vurdering av beslutningskompetanse. Rapport 2011:2. Oslo: Senter for medisinsk etikk, UiO, 2011. https://www.med.uio.no/helsam/tjenester/kunnskap/etikk-helsetjenesten/praksis/systematisketikkarbeid/ace2012.pdf Lest 19.2.2020.

16. Lundeberg IR, Mjåland K, Søvig KH. Tvang i rusfeltet. Oslo: Gyldendal, 2014.

17. Kapur N, Cooper J, King-Hele $S$ et al. The repetition of suicidal behavior: a multicenter cohort study. J Clin Psychiatry 2006; 67: 1599-6o9. [PubMed][CrossRef]

18. Syse A. Psykisk helsevernloven med kommentarer. 3. utg. Oslo: Gyldendal, 2016.

19. Aasland OG, Husum TL, Førde R et al. Between authoritarian and dialogical approaches: Attitudes and opinions on coercion among professionals in mental health and addiction care in Norway. Int J Law Psychiatry 2018; 57: 106-12. [PubMed][CrossRef]

Publisert: 7. oktober 2020. Tidsskr Nor Legeforen. DOI: 10.4045/tidsskr.20.0315

Mottatt 7.4.2020, første revisjon innsendt 28.5.2020, godkjent 9.6.2020.

(C) Tidsskrift for Den norske legeforening 2023. Lastet ned fra tidsskriftet.no 26. april 2023. 